\title{
China's NME status at the WTO: analysis of the debate
}

\author{
Mirek Tobiáš Hošman \\ Alma Mater Studiorum Università di Bologna, Bologna, Italy
}

\begin{abstract}
Purpose - Although officially ended in July 2020, China's dispute about its non-market economy (NME) status at the World Trade Organization (WTO) is far from being resolved. The NME status enables China's counterparts to disregard Chinese prices in antidumping proceedings and instead use the so-called surrogate country methodology. This paper aims to structure and analyze the complex debate, which emerged with the disputes China has filed against the European Union and the USA at the WTO, and therefore provide a point of reference for future analysis of and debates about China's NME status.
\end{abstract}

Design/methodology/approach - The analysis is based on the existing academic literature on the topic and on the legal WTO-related documents (e.g. multilateral agreements, China's Accession Protocol, legal findings of the WTO dispute panels).

Findings - Four different interpretations of the respective legal documents about China's NME status are discussed and strong and weak aspects of these interpretations are pointed out. Also, several misunderstandings and mistakes appearing in the debate are clarified.

Practical implications - As the question of China's position at the WTO and its NME status has not been resolved yet and some authors believe that China will pursue its case again once the WTO Appellate Body revives its functionality, the analysis of the debate can serve as a point of reference for the academic debate and the future research on this topic. Moreover, it offers an introduction to China's NME position at the WTO for the newcomers to this topic.

Originality/value - Although China's NME status has been much discussed, there is no literature review that would structure the debate and point out some of the (dis)advantages of the respective arguments and interpretations. Rather than adding to the large corpus of literature about the NME status, this study takes this corpus as the object of its analysis.

Keywords WTO, Antidumping, DS516, NME, Non-market economy, Trade dispute mechanism, EU, USA, China

Paper type Literature review

\section{Introduction}

Among the many challenges the World Trade Organization (WTO) is facing right now - be it the need to quickly find a new Director-General who will replace the early-resigned Roberto Azevedo, the ongoing trade conflict between the USA and China or the deteriorating judicial system manifested by the suspension of the Appellate Body functioning - there is

(C) Mirek Tobiáš Hošman. Published by Emerald Publishing Limited. This article is published under the Creative Commons Attribution (CC BY 4.0) licence. Anyone may reproduce, distribute, translate and create derivative works of this article (for both commercial and non-commercial purposes), subject to full attribution to the original publication and authors. The full terms of this licence may be seen at http:// creativecommons.org/licences/by/4.0/legalcode

The author would like to thank this journal's anonymous referees for their valuable comments. The author would also like to express his gratitude to Oldřich Krpec and Maria Lucia Boi for their insight and support.

Received 20 September 2020 Revised 9 November 2020 5 December 2020 Accepted 6 December 2020
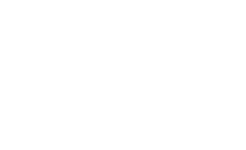
JITLP 20,1

one issue that seems to be off the table, which is China's dispute over its non-market economy (NME) status.

The dispute officially ended in July 2020 with the authority of the panel in the EU-China dispute (DS516) lapsing after a 12-month suspension of the case. China started its dispute at the end of 2016 by filing lawsuits against the USA and the European Union (EU) at the WTO. This step unleashed enormously complex debate among trade experts and states' representatives and the disputes were given significant importance from the involved parties as well. The US Ambassador to the WTO, Robert Lighthizer, called it "the most serious litigation matter that we have at the WTO right now" indicating that a possible ruling in China's favor would be "cataclysmic" for the WTO (US Committee on Finance, 2017, p. 12). China also considered the dispute "the most important live issue in WTO antidumping law" which "concerns the credibility of the dispute settlement mechanism, the integrity of the WTO and the membership's faith in the multilateral trading system" (Xiangchen, 2017, p. 14).

Although it may seem that the debate is over, China lost and will have to accept its position at the WTO, the underlying problems remain to be extremely relevant and it is reasonable to assume that the antidumping practices and legislature - on the WTO level and on the level of the nation-state - will continue to evolve in light of the legal debate about China's NME status. Professor Mark Wu from Harvard Law School pointed out that:

[...] the WTO cases on China's market economy status represent but the opening salvo in what will be a multi-stage trade confrontation between China and its trading partners in the coming years (Wu, 2018, p. 6) and that [h]istory will likely judge the debate over China's market economy status as having contributed to the [global trading system's] crisis and the contours of its eventual resolution (Wu, 2018, p. 7).

Given the importance of China's NME status at the WTO, this article tries to structure and analyze the complex, often blurry and sometimes rather technical debate surrounding the supposed expiration of the status in 2016. The aim of the article is to provide a point of reference for future analysis of and debates about the NME status. For this purpose, I identify four different interpretations of Article 15 of China's Accession Protocol (CAP) [1], - the legal foundations of the NME status - related to the abovementioned expiration. I examine the main arguments of these interpretations and I try to point out their strong and weak aspects based on the basic principles of international treaty interpretation and the WTO antidumping framework. Furthermore, certain misunderstandings and confusions appearing in the debate are clarified and several mistakes are corrected.

The article proceeds as follows: the first section presents the general antidumping framework within the WTO, the second section provides the necessary information about China's NME status, the third section analyzes differing interpretations of Article 15 of CAP and the fourth section concludes.

\section{World Trade Organization antidumping framework}

The legal basis for antidumping behavior and possible anti-dumping measures is nowadays provided by the Article VI of the General Agreement on Tariffs and Trade (GATT) and the Agreement on Implementation of Article VI of the GATT 1994, generally referred to as the Anti-Dumping Agreement (ADA).

The basic method of antidumping duties calculation that the investigative authority (IA) uses is the price comparison between the domestic price and the export price of the same product (Article VI:1(a); ADA 2.1). If for some reason, the domestic price is not available, other methods which may be used include comparing export prices to the 
country of the investigating authority and a third country (Article VI:1(b)(i); ADA 2.2) and comparing the export price to the constructed price of production in the country of origin (Article VI:1(b)(ii; ADA 2.2). The relevant parts of the Article VI:1 of the GATT are as follows:

For the purposes of this Article, a product is to be considered as being introduced into the commerce of an importing country at less than its normal value, if the price of the product exported from one country to another:

(a) is less than the comparable price, in the ordinary course of trade, for the like product when destined for consumption in the exporting country or,

(b) in the absence of such domestic price, is less than either:

(i) the highest comparable price for the like product for export to any third country in the ordinary course of trade or;

(ii) the cost of production of the product in the country of origin plus a reasonable addition for selling cost and profit (GATT, Article VI:1).

The relevant passages of the ADA Article 2 state the following:

For the purpose of this Agreement, a product is to be considered as being dumped, i.e. introduced into the commerce of another country at less than its normal value, if the export price of the product exported from one country to another is less than the comparable price, in the ordinary course of trade, for the like product when destined for consumption in the exporting country (ADA 2.1).

When there are no sales of the like product in the ordinary course of trade in the domestic market of the exporting country or when because of the particular market situation or the low volume of the sales in the domestic market of the exporting country, such sales do not permit a proper comparison, the margin of dumping shall be determined by comparison with a comparable price of the like product when exported to an appropriate third country, provided that this price is representative or with the cost of production in the country of origin plus a reasonable amount for administrative, selling and general costs and for-profits (ADA 2.2).

If a difference between the prices, with the export price lower than the price of comparison, is found (i.e. the margin of dumping) and if the complaining company can prove an injury stemming up from the dumping activity of another company, the antidumping duty can be imposed (GATT, Article VI:6; ADA Article 3). This duty cannot exceed the margin of dumping (GATT, Article VI:2 and VI:3; ADA Article 9.3) (see the respective legal documents for additional information).

Arguably the most controversial calculation methodology is the so-called surrogate country methodology, which allows the investigative authorities to ignore the domestic prices and replace them with surrogate prices. The surrogate country methodology is nothing new in the WTO system and its history in the multilateral trade environment dates back to 1955. At that time, Czechoslovakia proposed an interpretative note to Article VI of the GATT, which would deal with such countries, where the method of price comparison between domestic and export prices is not appropriate due to the significant presence of the state in the economy. The state, the argument goes, distorts domestic prices and marks them useless for price comparison. This debate led to the implementation of the Second Interpretative Ad Note to the Article VI:1 of the GATT [2], which now provides a part of the legal basis for the surrogate country methodology and states:

It is recognized that, in the case of imports from a country which has a complete or substantially complete monopoly of its trade and where all domestic prices are fixed by the State, special difficulties may exist in determining price comparability for the purposes of paragraph 1 and in such cases importing contracting parties may find it necessary to take into account the possibility 
JITLP 20,1

that a strict comparison with domestic prices in such a country may not always be appropriate (The Second Interpretative Ad Note to the GATT Article VI:1)

Other legal documents that are often mentioned in connection with the surrogate country methodology are Articles 2.7 and 2.2 of the ADA, where the "particular market situation" (PMS) condition is mentioned. The PMS notion has been used in antidumping investigations by numerous countries for many years. Australia belongs to the most active states in this field (Zhou, 2018a, p. 612), especially against China, which Australia recognized as a market economy in 2005 as a precondition for the negotiation of the China-Australia Free Trade Agreement. In fact, according to Zhou and Percival (2016, pp. 865-866), the officials from the US and the EU have been conducting consultations with Australian authorities on how the PMS notion can be used in antidumping investigations.

The fact that the PMS notion is being used to justify the recourse to surrogate country methodology does not mean that this matter is not extremely controversial. Several disputes have taken place at the WTO dealing with the antidumping methodology connected with the PMS (see, e.g. EU-Biodiesel (DS473), EU-Cost Adjustment Methodologies (DS474; DS494) or Australia-Anti-Dumping Measures on A4 Copy Paper (DS529)). In addition, the functioning and legality of the PMS within the WTO legal system remains unclear and needs to be clarified by the authorities (see details in e.g. Zhou, 2018a, p. 632; Zhou, 2018b, 2017; Joshi, 2018; de Kok, 2016, pp. 530-532; Zhou and Percival, 2016).

Finally, the surrogate country methodology can be used against states that have NME status. However, there are no multilateral rules or criteria describing NME conditions and the NME status is nowhere to be found in the WTO legal framework (Nedumpara and Subramanian, 2018, p. 34). NME conditions and the so-called NME methodology (surrogate country methodology enabled by the NME status) are usually incorporated in accession protocols and working party reports of concrete members of the WTO. For instance, the surrogate country methodology was brought up in dealing with the accession of Poland, Romania and Hungary to the GATT in the late 1960s and early 1970s (Miranda, 2018, p. 71). Each of these states had in its accession protocol an explanation of the antidumping rules and conditions, as well as the surrogate country methodology notion. Interestingly, as pointed out by Washington (2018, p. 289), the authority to use the surrogate country methodology in antidumping investigations was recognized by the respective Working Party Reports as based on Article VI of the GATT and none of the protocols contained legally operative language about using the surrogate country methodology.

Similarly, China's NME status was also set up in its Accession Protocol and the next section introduces the context, which is necessary for the analysis of the debate about the expiration of parts of Article 15 of CAP.

\section{China's non-market economy status: the context}

The NME status for China was set up in Article 15 of its Accession Protocol. The relevant parts state the following:

(a). In determining price comparability under Article VI of the GATT 1994 and the AntiDumping Agreement, the importing WTO Member shall use either Chinese prices or costs for the industry under investigation or a methodology that is not based on a strict comparison with domestic prices or costs in China based on the following rules:

(i) If the producers under investigation can clearly show that market economy conditions prevail in the industry producing the like product with regard to the manufacture, production and sale of that product, the importing WTO Member 
shall use Chinese prices or costs for the industry under investigation in determining price comparability.

(ii) The importing WTO Member may use a methodology that is not based on a strict comparison with domestic prices or costs in China if the producers under investigation cannot clearly show that market economy conditions prevail in the industry producing the like product with regard to manufacturing, production and sale of that product.

China's NME status at the WTO

(d). Once China has established, under the national law of the importing WTO Member, that it is a market economy, the provisions of subparagraph (a) shall be terminated provided that the importing Member's national law contains market economy criteria as of the date of accession. In any event, the provisions of subparagraph (a)(ii) shall expire 15 years after the date of accession. In addition, should China establish, pursuant to the national law of the importing WTO Member, that market economy conditions prevail in a particular industry or sector, the NME provisions of subparagraph (a) shall no longer apply to that industry or sector.

According to Article 15 of CAP, there are two basic methodologies that the IAs can use when they deal with China for 15 years after its accession to the WTO. First, the IA can use the Chinese prices and costs if the producer under investigation "can clearly show that market economy conditions prevail in the industry" (subparagraph 15(a)(i)). Second, if the producer cannot clearly show that the market economy conditions prevail in the industry, the IA can use "a methodology that is not based on a strict comparison with domestic prices or costs in China" (subparagraph 15(a)(ii)). In addition, paragraph 15(d) adds two more conditions. First, once China obtains a market economy status (MES) from a certain country, the whole paragraph 15(a) shall be terminated. That means that the IA of such a country cannot use an antidumping methodology based on Article 15. Second, the provisions of subparagraph 15(a)(ii) shall expire 15 years after the date of accession in any event. What that means is unclear and at least four distinctive interpretations can be found on this topic in the literature (see the next section of this article).

CAP serves as a sort of supplement to the WTO rules described in the previous section. In other words, any member state can use the methodologies described above and when dealing with China, its Accession Protocol provides specific rules for antidumping behavior toward it as long as the member state does not grant China the MES under its national legislation. As I noted above, there are no multilateral rules for assessing the market economy status of a country and the term "NME" does not have a definition in the WTO documents. It is, therefore, understandable that China put the goal of acquiring the MES on top of the list of its foreign policy agenda and mounted a vigorous diplomatic campaign to be treated as a market economy by its trade partners (Hufbauer, 2016, p. 26; Pan, 2015, p. 748; Urdinez and Masiero, 2015, p. 160; Rémond, 2007, pp. 346-8; Jinshan, 2007, p. 172). To this day, more than 80 countries acknowledged China as a market economy. Among New Zealand (April 2004), Australia (April 2005), Peru, Chile and all ASEAN countries (Bellora and Jean, 2016, p. 3). China also tried to persuade the US and the EU to change their view, however, both of them exercised the assessment of China's economy [3] several times and both have been reluctant to give China the MES. Chinese officials have interpreted the paragraph (d) as terminating the NME status 15 years after China's accession to the WTO, i.e. on December 11, 2016. However, as the final date was approaching, the US and the EU declared that they do not plan to automatically grant China MES and that they will continue to treat China as an NME in their anti-dumping proceedings. Therefore, one day after the 
JITLP 20,1

supposed final day of its NME status, on December 12, 2016, China filed a lawsuit against the US and the EU at the WTO.

Since the beginning, China focused primarily on the case against the EU under the code DS516, which in March 2017 led to the establishment of the panel in accordance with Article 6 of the Understanding of Rules and Procedures Governing the Settlement of Disputes (DSU). On November 26, 2018, the Chair of the panel informed the dispute settlement body that in light of the complexity of the legal issues covered in this dispute, the panel expected to issue its final report to the parties during the second quarter of 2019. However, on May 7, 2019, China requested the panel to suspend its proceedings in accordance with Article 12.12 of the DSU. The official reasons behind this decision are unknown (see some speculative accounts in Zhou and Noël, 2019, pp. 423-424). According to one trade official, who was close to the case, China was about to lose the bulk of the case and rather decided to halt the investigation before the results became public (Miles, 2019). In the case against the US under the code DS515, China requested two rounds of consultations, but then decided not to pursue the case further, and therefore the panel was not assembled in this dispute.

It is generally believed that the surrogate country methodology inflates the antidumping rates and motivates other states to use more antidumping measurements against China (Zhou, 2018a, p. 612; Lee et al., 2017, p. 4; Bellora and Jean, 2016, p. 2; Zhou and Percival, 2016, p. 864; Sandkamp and Yalcin, 2016, pp. 79-80; Urdinez and Masiero, 2015, p. 169; Jinshan, 2007, p. 175; GAO, 2006; Messerlin, 2004, p. 123). For instance, the US antidumping margins against China have averaged $154 \%$ as compared to an average of $49 \%$ against other countries. The EU anti-dumping margins against China have averaged $61 \%$ as compared to an average of 31\% against other countries (Prusa, 2017, p. 620).

The amount of trade affected by the status is difficult to measure due to the complexity of concrete antidumping calculations and the lack of comparable data. Bown, who in his analysis focused not only on antidumping measures but also on other temporary trade barriers (such as countervailing duties and safeguards mechanisms) argues that about 7\% of China's exports to G-20 countries were subject to G-20-imposed trade barriers, which roughly accounts to US $\$ 100 \mathrm{bn}$ in nominal terms. However, as Bown concludes: "even a complete revocation of China's NME status is extremely unlikely to unleash an additional $\$ 100 \mathrm{bn}$ in pent-up Chinese exports onto global markets" and "estimates of the lost trade flow associated with any refusal to provide MES are probably much closer to $\$ 10 \mathrm{bn}$ - and, perhaps, even $\$ 1 \mathrm{bn}$ - than $\$ 100 \mathrm{bn”}$ (Bown, 2016).

\section{The views on China's non-market economy status}

This section analyzes four different interpretations of Article 15 of the CAP and its expiration. The analyzed views are:

- magical deadline;

- urban myth that seems to have gone global;

- shift of the burden of proof; and

- something remains.

\section{View \#1: Magical deadline}

According to the "magical deadline" (Tietje and Nowrot, 2011, pp. 7-8) view, China should automatically receive the MES after the expiration of subparagraph 15(a)(ii). It is believed that although Article 15(d) mentions only the expiration of subparagraph 15(a)(ii), the rest of paragraph 15(a) does not provide sufficient space for applying the NME methodology. There are several arguments that the proponents of this view have put forward [4]. 
First, the chapeau was added later by the US and it was not involved in the previous drafts of CAP. Even in the last draft, the negotiators adopted the word "may" and not the word "shall" which can be found in the final document. Therefore, Rao claims that:

A review of the drafts still indicates that the addition of the chapeau could be largely intended to reiterate the conditional options of the importing Member, instead of obligating it to use alternate methodologies (Rao, 2013, p. 164).

Furthermore, the chapeau states that the methodology should be "based on the following rules" explained in subparagraphs 15(a)(i) and 15(a)(ii). As the chapeau is based on both subparagraphs, it cannot continue to work without subparagraph 15(a)(ii). The remaining parts of the chapeau become meaningless because "the condition it depends on to be invoked no longer exists” (Rao, 2013, p. 161; see also Zhou, 2017, pp. 350-351; Fang, 2018, p. 116).

Second, according to some, paragraph 15(d) states that "in any event" the WTO members may not use the surrogate country methodology against Chinese exports beyond the 15 years transition period following China's accession to the WTO (Cheng, 2016, p. 30). The expression "in any event" is decisive here and if the NME methodology is used after this deadline, then it would mark paragraph 15(d) useless and why would the negotiators then decide to adopt it (Cheng, 2016, p. 30)? This argument is connected with the effective treaty interpretation principle, adopted by the WTO Appellate Body, which "requires us to give meaning to every term of the provision" (see Appellate Body Report on Canada-Renewable Energy, paragraph 5.57; see also reports on US-Gasoline and Japan-Alcoholic Beverages) [5].

Third, there is no legal basis for using the NME methodology against China which can be found in the language of the Accession Protocol after subparagraph 15(a)(ii) expired. This conclusion is supported by the Report of the Working Party on the Accession of China which, it is argued, constitutes the relevant context for the interpretation of Article 15 (Suse, 2017, p. 959). The chapeau of paragraph 151 of China's Working Party Report mentions subparagraph 15(a)(ii) instead of the whole paragraph 15(a) when discussing the NME treatment of Chinese exports, and therefore "it can be argued that the Working Party's understanding was that the second subparagraph is the true legal basis for the use of NME methodologies" (Suse, 2017, p. 960). Having said that, it should be concluded that those legal texts enabling the use of the NME methodology are no longer active, and thus the NME methodology should not be used against China.

Fourth, many statements made by officials and institutions representing the US and the EU may be found that should be taken into account when interpreting Article 15. Two reasons were put forward for such an approach. First, these statements provide the interpretative context as allowed by the Vienna Convention on the Law of Treaties. Second, the Appellate Body explained that the unilateral statements of individual negotiating parties may be useful in determining "the reality of the situation which the parties wished to regulate by means of the treaty and [...] for discerning the common intentions of the parties" (see Appellate Body Report, EC - Chicken Cuts, paragraphs 283 and 289). When commenting on the 1999 USA-China bilateral agreement (which later provided the basis for Article 15 of CAP), the US chief negotiator and then US Trade Representative (USTR) Charlene Barshefsky said in February 2000 that “China's WTO entry will guarantee our right to continue using our current 'NME' methodology in anti-dumping cases for 15 years after China's Accession to the WTO” (Barshefsky, 2000). Similarly, then US Secretary of Commerce William Daley stated that:

China has agreed to guarantee our right to continue using our current methodology (treating China as an NME) in antidumping cases for 15 years after China's accession to the WTO (Suse, 2017, p. 961). 
JITLP 20,1

A statement posted on the website of the White House after the conclusion of the 1999 agreement says that:

We will be able to maintain our current antidumping methodology (treating China as an NME) in future anti-dumping cases without the risk of the legal challenge. This provision will remain in force for 15 years after China's accession to the WTO (Suse, 2017, p. 961).

As for the Accession Protocol itself, a note on the USTR's website stated that:

[... ] [f]or 15 years after China's accession to the WTO, the US and certain other WTO members will continue to have the ability to use a special NME methodology for measuring dumping in antidumping cases against Chinese Companies (Suse, 2017, p. 962; see another statement in Xiangchen, 2017, pp. 9-11).

Fifth, it is not necessary that China graduates to the MES in the respective national legislations. The members of the WTO can continue to treat China as an NME country for whatever reasons (e.g. political). Nonetheless, the NME status cannot any longer justify the application of the NME methodology in antidumping calculations (Zhou, 2017, p. 354).

Sixth, the Appellate Body has already interpreted the meaning of paragraph 15(d) in one case and it observed that:

Paragraph 15(d) of CAP establishes that the provisions of paragraph 15(a) expire 15 years after the date of China's accession (that is, December 11, 2016) [...] paragraph 15(a) contains special rules for the determination of normal value in antidumping investigations involving China. Paragraph 15(d), in turn, establishes that these special rules will expire in 2016 (Appellate Body Report EC-Fasteners, paragraph 289).

Fang, for instance, argues that it is oblivious that the Appellate Body referred to the whole paragraph 15(a) and not to the subparagraph 15(a)(ii) (Fang, 2018, p. 109). This seems to imply that the understanding of the Appellate Body is that the whole Section 15(a) should expire.

Finally, the use of the NME methodology tends to ignore the development of the market economy in China, which is not significantly different from other countries around the world. According to some authors, China either became or is on the right way to become a market economy and/or does not influence the economy in a substantively different way than others (Cheng, 2016, p. 30; Rémond, 2007, p. 348; Watson, 2016, 2014, p. 8). Some authors also speculate if China is dumping at all and its low prices are not just a consequence of its comparative advantage and cheap labor (see a short overview of these views in Rinaldi-Larribe et al., 2009, p. 115; see also Yalcin et al., 2016, p. 34). Nicely claims that:

The current NME methodologies [are] being used throughout the world as outdated vestiges of the cold war. They do not take into account sufficiently the fact that the countries we call NMEs at least the ones that are active members of the global economy and members of the WTO - have thriving market economies. The fact that the state is involved in the economy in these countries is not significantly different $[\ldots]$ from the manner in which many governments across the globe influence the market (Nicely, 2014, pp. 160-161).

It is acknowledged by some authors that the only remaining basis for using the surrogate country methodology is the Second Interpretative Ad Note to Article VI:1 of the GATT, as noted above. On the contrary, some authors claim that the usage of the surrogate country methodology is prohibited in the WTO system, see e.g. William Watson from the CATO Institute (2016, p. 16, 18, 20, see also Urdinez and Masiero, 2015, p. 161; Tietje and Sacher, 2018, p. 8). However, even those authors, who correctly bring attention to the Second Ad 
Note, often claim that the conditions of the note cannot possibly be met, and therefore China should be protected against the surrogate country methodology after passing the magical deadline of December 12, 2016 (Rao, 2013, p. 167; Tietje and Nowrot, 2011, p. 11; de Kok, 2016, p. 528). China itself argues that the application of the surrogate country methodology is inconsistent with the most-favored-nation (MFN) principle and the general rules for the antidumping calculation under Article 2 of ADA (Zhou, 2017, p. 347; Nedumpara and Subramanian, 2018, pp. 22-23). Chinese Ministry of Commerce insisted in one recent antidumping investigation that the "US is obligated to no longer use a surrogate methodology with respect to all antidumping determinations targeting Chinese products after December 11, 2016” (USDOC, 2017, p. 9).

As exhaustive as this list of arguments may seem, there are, expectedly, many problems with the "magical deadline" view.

First, the fact that the chapeau was added later does not necessarily mean that it only reiterates what was already stated in the previous drafts. Quite the contrary, as observed by O'Connor, the logical option seems to be that the fact that the US insisted on adding the chapeau makes it likely that it was intended to have some effect (O'Connor, 2016a, p. 4). Furthermore, there is nothing in the text that would imply that the meaning of "based on the following rules" must entail all the stated rules and not just some of them, if other rules expire (O'Connor, 2016a, p. 3).

Second, the effective treaty interpretation principle is a double-edged weapon. In this case, it may be argued that the continuing use of the NME methodology contradicts this principle because it marks paragraph 15(d) useless. However, the opposite view - such that paragraph 15(d) prohibits the use of such methodology - marks the rest of paragraph 15(a) and subparagraph 15(a)(i) useless. Moreover, the interpretation of the respective section of Article 15 by Cheng and others, according to which the WTO members may not use the surrogate country methodology against Chinese exports after December 11, 2016, does not seem to be correct. Not only it is not specifically written in CAP and it does not automatically follow the expiration of subparagraph 15(a)(ii) but this view also ignores the multilateral legal basis for using the surrogate country methodology as discussed at the beginning of this article.

Third, it is true that CAP does not specifically mention the surrogate country methodology besides the expired subparagraph 15(a)(ii), however, this does not automatically mean that this methodology is, therefore, prohibited. Moreover, it has been stated by the WTO Dispute Panel that paragraph 151 of the Working Party Report is not considered an integral part of CAP, and therefore can only be taken into account as an existing condition at the time of releasing the Accession Protocol (see Panel Report in EU-Footwear, paragraph 7.181; see also Nedumpara and Subramanian, 2018, p. 33).

Fourth, as for the statements by officials presented above, if we accept that they should be given such weight in interpreting a treaty - it is one thing to provide a context for interpretation and another thing to base our interpretation on these statements - and if we accept that some of them deal with a different agreement (which seems quite marginal given the clear connection between the documents), we can conclude that when read carefully, these statements do not contradict a further use of the surrogate country methodology. What they do claim is that for 15 years, the US and other members of the WTO can use this methodology without the risk of a legal challenge (if they follow the agreed rules). This does not automatically imply that after this period, the methodology is prohibited.

Fifth, although the approach according to which China may still be considered an NME country without this status having any effect on the antidumping proceedings seems appealing, the problem is that the NME status basically does not have any other real usage 
JITLP 20,1

besides antidumping proceedings. It was originally created to deal with non-market economies in antidumping investigations and it remains to be closely tied with antidumping to these days (GAO, 2006, p. 4; Tietje and Nowrot, 2011, p. 2; Washington, 2018, p. 274). Furthermore, the strategy of loosening the connection between the NME status and the surrogate country methodology is not a clever one. Australia recognizes China's MES and to China's resentment - is still using the surrogate country methodology based on the PMS notion mentioned above (Zhou and Percival, 2016, pp. 887-91). Under this logic, Australia could claim that there is no connection between anti-dumping proceedings and the NME status, which is hardly something China would appreciate.

Sixth, the Appellate Body interpretation of paragraph (d) was made in a different case and it was clearly obiter dictum (not a legally binding part of the decision) [6], and therefore does not constitute a legally binding definition (Kaszubska, 2017, pp. 9-10; Fang, 2018, pp. 109-110).

Generally, the main problems of this view are that it ignores other documents within the WTO system enabling the use of the surrogate country methodology and that it cannot explain why the remaining sections of Article 15 should be marked meaningless after the 15 years period as there is nothing that would force us to follow this interpretative approach. Therefore, it seems to be an unreasonably strong interpretation. The surrogate country methodology can be used against China in antidumping investigations in accordance with the WTO rules even without CAP. Actually, it is even commonly used between two market economies (Kelly, 2014, p. 113).

View \#2: Urban myth that seems to have gone global

The radically opposing to the "magical deadline" view is the "urban myth that seems to have gone global" (O'Connor, 2011) view. Simply put, authors holding this view argue that nothing substantial changes after the "magical deadline" of December 11, 2016, and business can continue as usual [7]. Bernard O'Connor is often mentioned as the leading proponent of this view (Washington, 2018, p. 283; Kaszubska, 2017, p. 8; Tietje and Nowrot, 2011, p. 2). He states:

Despite all these affirmations, there is no deadline. There is no provision setting any date in the WTO agreements themselves and there is no deadline in the protocol signed by China when it acceded to the WTO. The idea that there is a deadline is an urban myth that seems to have gone global. It has gone viral even in a world w[h]ere the underlying agreements are freely available to all on the internet (O'Connor, 2011).

According to the view of O'Connor, CAP does not automatically guarantee China the MES after December 11, 2016. He argues that "If [China] can establish that it is a market economy then some of the transitional provisions on comparison methodologies will terminate" (O'Connor, 2011). In other words, only "one specific comparison methodology set out in one subparagraph of the Article will expire, in any event, 15 years after Chinese accession" (O'Connor, 2011). This does not mean that China will automatically receive the MES.

Moreover, the proponents of this view also argue that the remaining parts of Article $15-$ the chapeau, subparagraph 15(a)(i) and remaining parts of paragraph 15(d) - provide a sufficient basis for the NME methodology (O'Connor, 2016a, 2011; Washington, 2018, p. 283; Brown, 2016, p. 23). This was referred to as "a contrario" interpretation, which is a reasoning based on an argument from the contrary or on negative reasoning from another argument. In other words, if Chinese producers cannot prove market economy conditions the "a contrario" interpretation means that non-Chinese costs and prices can be used (Nedumpara and Subramanian, 2018, p. 25). Also, the remaining parts of paragraph 15(d) require Chinese producers to prove under the national law of the importing country that market conditions 
prevail in their industry. This is clearly an exception in the WTO system because under normal conditions only the prices of the producer are taken into account (Lee, 2016, p. 11). However, in this case, the prices of the industry may be taken into account (O'Connor, 2016a, p. 3). Therefore, the view that says that after the magical deadline China has to be treated like any other member of the WTO is mistaken. In addition, the Appellate Body arguably concluded that Article 15 of CAP constitutes a differential treatment for China in EC-Fasteners case (see the Appellate Body Report, WT/DS397/AB/R, 2011, paragraphs 287, 290).

In addition to the argument presented in the section about the magical deadline view,

China's NME status at the WTO some argue that there is clear evidence that China is not a market economy, and therefore insisting that all the WTO members treat China as a market economy would be contrary to the purpose of Article 15 (Price et al., 2015, pp. 2-3). This purpose, as can be found, e.g. in the Working Party Report on China's Accession, is to help China to continue its progress toward becoming a full market economy (Washington, 2018, p. 285; Nedumpara and Subramanian, 2018, p. 32). Adding to this view, it was proposed to read Article 15 together with Article 9 of CAP, in which China commits itself that its domestic prices will be determined by market forces. Both provisions are understood as having a reciprocal nature and as China has not removed price distortions, the importing countries do not have to be obliged to take these prices into account (Kaszubska, 2017, p. 8).

As in the previous case, there are several difficulties connected with this view. First of all, as already mentioned above, loosening the ties between the NME status and NME methodology is not a convincing strategy and misses the real issue - the usage of nonChinese prices in antidumping investigations.

Second, although the remaining parts of Article 15 still continue to exist and they point at some hints about using an alternate methodology, it is hardly the case that the NME methodology can be used as nothing has ever changed (Kaszubska, 2017, p. 9). Not only is that nowhere to be found in CAP but more importantly, this would mark the expired sections of Article 15 useless. As shown above, this strongly contradicts the effective treaty interpretation principle. Simply put, if the situation remains the same after the expiration of subparagraph 15(a)(ii), why was that subparagraph ever considered relevant? And why was it included in CAP at all?

Third, arguments pointing to the economic conditions seem to be misleading. As discussed by many authors, the NME status is not truly connected with economic performance or concrete market situation (Pan, 2015, pp. 751-756; Rinaldi-Larribe et al., 2009, p. 117; Detlof and Fridh, 2006, p. 7). Moreover, it is not clear why certain economic conditions should matter for a legally binding interpretation of Article 15. As for the connection between Article 15 and Article 9, there is nothing that would force us to understand these two provisions as being of a reciprocal nature.

Generally, the implication of this view that marks the expired sections useless even before its expiration indicates that also this interpretation is too strong. However, two conclusions seem to be correct. First, the remaining parts of Article 15 continue to be active. As Messerlin pointed out "[i]t is almost impossible to eliminate a provision included in a country's protocol of accession" (2004, p. 124). Second, China can be treated differently on the basis of these remaining parts than other WTO members in the future.

\section{View \#3: Shift of burden of proof}

The "shift of burden of proof" view can be understood as a sort of middle ground between the two views analyzed above. It is also the view that the US and the EU adopted in their respective disputes considering China's NME status (see First Written Submission by the EU, 2017; and Third-Party Submission of the US, 2017). The EU even changed its domestic anti-dumping regulations to put them in accordance with this interpretative approach. 
JITLP 20,1

According to this view, after December 11, 2016, a shift in the burden of proof took place. Before this deadline, other WTO members could suppose that China is an NME country and Chinese producers had to prove otherwise if they wanted to gain a different treatment (although this has not happened often and applications from Chinese companies have been often unsuccessful, see e.g. Xu and Tang, 2009, p. 70) [8]. After the deadline, this proof has to be made by other WTO members' investigative authorities. If they can prove that NME conditions prevail in the Chinese industry under consideration, they can continue to treat products of such industry as coming from an NME country, and therefore use the NME methodology (Miranda, 2014). Besides, this shift in the burden of proof, nothing changes after December 11, 2016 (Joshi, 2018, p. 203). The EU explained this view in its First Written Submission to its case with China as follows:

[I]f there is no evidence of either market economy conditions or NME conditions, the investigating authority cannot, on the basis of the new Section 15, apply a methodology that is not based on a strict comparison with domestic prices or costs in China. Second, if there is some evidence of market economy conditions (and no evidence of NME conditions), the investigating authority also cannot, on the basis of the new Section 15, apply a methodology that is not based on a strict comparison with domestic prices or costs in China. Third, in weighing some evidence of market economy conditions against some evidence of NME conditions, there is now no China-specific rule in Section 15 placing the burden of proof on Chinese exporters (2017, paragraph 110).

The reasons for this shift of the burden of proof can be found either in the remaining sections of CAP or they can be based on the WTO legal documents which allow for using the surrogate country methodology (Tietje and Nowrot, 2011, p. 10; Telep and Lutz, 2018, pp. 700-701; Fang, 2018, p. 112). The non-exclusive understanding concerning the remaining section of Article 15 was already presented above and the shift of the burden of proof is based on such interpretation of the remaining parts of paragraph 15(d). The first sentence of this paragraph says that "[o]nce China has established, under the national law of the importing WTO Member, that it is a market economy, the provisions of subparagraph (a) shall be terminated [...]." The third sentence says:

Should China establish pursuant to the national law of the importing WTO Member, that market economy conditions prevail in a particular industry or sector, the NME provisions of subparagraph (a) shall no longer apply to that industry or sector.

These provisions can be read as placing the burden of proof on the importing country and not on China, as was proposed by the US (see Third-Party Submission of the US, 2017, Attachment 1, paragraphs 8.5.5-8.5.6). This reading would mean that the expired subparagraph 15(a)(ii) required China to demonstrate the market economy conditions (Telep and Lutz, 2018, p. 701).

One can easily find many misunderstandings in the debate about this view connected with the views and arguments already presented above. For instance, Fang (2018, pp. 116-118) claims that after the expiration of subparagraph 15(a)(ii), the whole Article 15(a) is terminated and China must be treated in the same way as other WTO members. I have already discussed the shortcomings of similar views. Tietje and Nowrot (2011, p. 10) acknowledge that a shift of the burden of proof occurs with the expiration of subparagraph 15(a)(ii) and the surrogate country methodology based on the respective WTO documents can be used against China, however, the respective document for them is only the Second Ad Note to the article VI:1 of the GATT. According to them meeting the conditions of the Second Ad Note is almost impossible, the surrogate country methodology cannot be used any further. Nonetheless, this approach completely misses the PMS notion introduced above.

The shift of the burden of proof view is able to escape the counterintuitive consequences of the previous view according to which there is no change after December 11, 2016. 
Now there is a change, something significant happened, however, the NME methodology can still be used and China can still be treated differently from other WTO members. Nevertheless, the problem of this view is that there is nothing to be found in the Accession Protocol that would actually provide the basis for the shift of the burden of proof (Zhou and Peng, 2018, pp. 512-513). Even the reading of the remaining parts of paragraph 15(d) suggested by the US is speculative and not really convincing from the textual point of view. The inverted interpretation according to which China has to prove that market economy conditions prevail is at least as probable as the reading suggested by the proponents of this status at the WTO view (Fang, 2018, p. 112). O'Connor argues:

The first and third sentences of Article 15(d) make clear that it is China, which must establish that it has become a market economy (for the whole economy or for particular industries or sectors of the economy) and that the standard to be met in that evaluation is as set out in the law of the importing WTO Member (2016a, p. 2).

Arguably, by proposing this interpretation, the US and the EU are somehow trying to improve the position of China in the WTO system. Although the NME methodology can still be used and it can still be based on the Accession Protocol (which is crucial if the other legislation concerning for instance the PMS notion will be clarified in the future), now the US and the EU have to prove that the specific company/industry/sector does not operate on market economy conditions. If they fail to do so, they cannot use the NME methodology based on the Accession Protocol.

\section{View \#4: Something remains}

According to the "something remains" view, which is being hinted at by Nedumpara and Subramanian (2018, pp. 21-34), the remaining parts of Article 15 provide a sufficient basis for using some alternate methodology. Therefore, similarly to the second and third views examined above, China is not entitled to automatically obtain the MES and it is not correct to claim that the surrogate country methodology is prohibited from the magical deadline onward. Tables 1 and 2 present the possible scenarios under this view according to subparagraphs 15(a)(i) and 15(a)(ii).

What distinguishes this view from the second view is that under this interpretation, there is a substantial change, which took place on December 11, 2016. Up until then, IAs could use the NME methodology according to the established rules and without the risk of legal challenges. After this date, it is not clear what the IAs can do, but the possibility for differential treatment is definitely open. If we take the chapeau into account, it states that a methodology "not based on a strict comparison with domestic prices and costs in China" may be used based on the rules expressed in subparagraphs 15(a)(i) and 15(a)(ii). As already

Scenario I:

Chinese exporter clearly shows that market economy conditions prevail in the industry

Scenario II:

Chinese exporter cannot clearly show that market economy conditions prevail in the industry

\author{
Outcome: \\ Mandatory use of Chinese domestic costs and prices \\ Outcome: \\ The investigative authority is not bound to use Chinese \\ domestic costs and prices. What the investigative \\ authority should do is not very clear. However, a \\ reference to the chapeau of Section 15 would imply that \\ the surrogate methodology could be applicable
}

Source: Nedumpara and Subramanian (2018, p. 24)

Table 1. Scenarios under Article 15(a)(i) 
JITLP

20,1

mentioned above, this reading is based on a non-exclusive understanding of the phrase "based on the following rules" (Nedumpara and Subramanian, 2018, p. 27). In other words, if one rule expired, the other is still active nonetheless. The question is, then, what this methodology actually entails. It may entail the surrogate country methodology, which disregard Chinese prices and costs totally or it may refer to a different possible methodology that somehow uses Chinese prices and costs but do not strictly compare them to the export prices, e.g. uses Chinese prices and costs as a starting point and then adjusts them in a certain way. In any case, this would provide for the change, which would explain the magical deadline in the Accession Protocol.

Contrary to the shift of the burden of proof view, according to this view, no shift of the burden of proof takes place. China still has to prove that market economy conditions prevail in a certain industry and if it is able to prove so, it has to receive market economy treatment (Nedumpara and Subramanian, 2018, p. 32; O'Connor, 2016a, p. 3). It is not the responsibility of other WTO members to prove that market economy conditions prevail in respective Chinese industries.

This interpretation is arguably the least elaborated; however, it is successful in avoiding the biggest shortcomings of the other views as they were analyzed above. It is true that according to the "something remains" view, it is not clear what methodology the IA can use and it is exactly this vagueness, which is the most serious shortcoming of this view. However, the important aspect of this interpretation is that there will always be room for differential treatment of Chinese exports based on CAP and this can be significant in the future. As the PMS notion and the Second Ad Note apply to every member of the WTO, one can expect that there will be a higher pressure from the international community to clarify their meaning and regulate them according to common rules. If this happens, it can be much more difficult to disregard domestic prices in antidumping investigations. However, according to something that remains view, such an option will always be provided for the antidumping investigations against China. In this sense, the vagueness of this interpretation could be useful for China's counterparts in the future.

\section{Concluding remarks}

After examining the four views on China's NME status, it is possible to draw a line between the first two and the last two views. The first two views do not seem to be convincing. They both fail to follow very important principles of international treaty interpretations, namely, the effective treaty interpretation principle. The first view seems to overlook the remaining parts of Article 15 or marks them useless without proper reasoning. Moreover, there is nothing in CAP that would automatically give China the MES and even when one chooses to ignore the parts of the Accession Protocol that arguably provide the basis for the continuation of the discriminatory treatment against China (which is controversial on its

Table 2.

Scenario I: $\quad$ Outcome:

Chinese exporter cannot clearly show that market economy conditions prevail in the industry

The investigative authority may use a method, which is not based on Chinese domestic costs and prices. In other words, the investigative authority can use third-country prices/surrogate prices or constructed value
Scenario under Article 15(a)(ii)
Source: Nedumpara and Subramanian (2018, p. 24) 
own), there are other WTO documents that allow the use of surrogate country methodology, and therefore other ways how the IAs can disregard Chinese prices.

The second view deals with some of the problems of the first view, however, its biggest problem is that it cannot explain what has actually changed on December 12, 2016. One cannot simply ignore the fact that a specific date is mentioned in the Accession Protocol, even more so if the remaining parts of the texts become confusing because of this expiration.

The last two presented views seem more convincing. Although the reasons for the shift of the burden of proof are rather vague, it arguably improves China's position in the antidumping proceedings. The vagueness of something that remains view represents its biggest shortcoming; however, it is precisely this vagueness that could be important in the future. In any case, it must be stated clearly that the last two views preserve a discriminatory treatment of China in the WTO.

China's position in the WTO and its NME status presents a major challenge for the multilateral trade regime for the upcoming years. Even though it may seem like the issue is now off the table as the dispute expired, the WTO currently finds itself in a very difficult position and it is hard to predict how it will handle the challenges posed by China's membership. Some authors, Zhou and Noël (2019), even believe that China will pursue its NME case again once the Appellate Body revives its functionality. Whichever the case, China's NME status does not seem to be resolved any time soon. In fact, it may be that the debate analyzed in this article is part of the first round of a larger battle and we currently find ourselves at half-time.

\section{Notes}

1. Other divisions of the interpretations are possible. Zhou, for instance, distinguishes only two views in the debate - one favorable to China (view \#1 in this text) and one against its claims (view \#2 in this text) (2017, pp. 348-349). Yalcin et al. (2016) distinguish four different views in a rather confusing way (automatic MES for China, no automatic MES for China, China remains an NME, MES for China) (p. 17). Different and rather speculative interpretations were also proposed. For instance, Fang claims that CAP could be interpreted by different methods than other WTO documents because of its "contractual nature" (Fang, 2018, p. 120).

2. The note was accepted by the Report of the 1954-55 Working Party on "Other Barriers to Trade" and it was brought into effect by the Protocol Amending the Preamble and Parts II and III of the GATT. This Protocol went into force on 7 October 1957 and the note, thus, became binding for all GATT members (see more details in Snyder, 2001, p. 383).

3. Reasons why China should not be treated as a market economy can be found in $\mathrm{Yu}$ (2019, p. 44), Brown (2016, p. 23), Wilson (2016, p. 19) Tietje and Sacher (2018, p. 5), Rémond (2007, p. 354), Morrison (2016, p. 83, 108). Opposite reasons can be found e.g. in Lu and Jiao (2019, pp. 52-4), Morrison (2016, p. 109), Lardy (2018, 2014).

4. To read more about this view, Graafsma and Kumashova (2014), Gatta (2014), Nicely (2014), Weija (2013), Watson (2014), Vermulst et al. (2016), de Kok (2016), Zhenghao (2016), Noel (2016), Yu and Guan (2017).

5. The effective treaty interpretation or effet utile is one of the fundamental principles of international treaty interpretation. It means that the interpreter cannot adopt a meaning that would reduce some parts of the treaty to redundancy or inutility. It has its foundation in the Roman doctrine of ut res magis valeat quam pereat (it is better for a thing to have effect than to be made void) (Nedumpara and Subramanian, 2018, p. 25).

6. The classical definition of obiter dictum is "an expression of opinion in regard to some point or rule of law, made by a judge in the course of a judicial opinion, but not necessary to the
China's NME status at the WTO 
JITLP 20,1

16

determination of the case before the court" (Black, 2010, p. 166) Dicta "are not the judicial determinations of the court, they are never entitled to the force and effect of precedents, in the same or other courts and do not preclude the rendering of a subsequent contrary decision" (Black, 2010, p. 176).

7. To read more about this view, O'Connor (2016a, 2016b), Miranda (2014, 2016), Stewart et al.. (2014), Ruessmann and Beck (2014).

8. The domestic legislature guiding decisions about differential treatment varies among states. For instance, in the $\mathrm{EU}$, the producer could receive a market economy treatment or individual treatment. The analysis made by Detlof and Fridh (2006) shows that antidumping duties when market economy treatment was applied were on average 28 percentage points lower than for those companies, which were not granted such treatment. In the case of individual treatment, the duties were on average 15 percentage points lower. Similar logic can be found in the case of the USA. The following table taken from Morrison (2019) shows six cases in which some Chinese producers obtained separate antidumping duties and compares them with NME duties and market economy duties used against a third market economy state.

\begin{tabular}{lccc}
\hline Product and year & $\begin{array}{c}\text { China NME } \\
\text { duty }\end{array}$ & $\begin{array}{c}\text { China separate } \\
\text { duty }\end{array}$ & $\begin{array}{c}\text { Market economy } \\
\text { duty }\end{array}$ \\
\hline Certain polyethylene terephthalate resin, 2016 & 126 & $105-118$ & $8-19$ \\
Certain uncoated paper, 2016 & 149 & 84 & $2-222$ \\
Certain crystalline silicon photovoltaic products, 2014 & 165 & $27-78$ & $12-28$ \\
Certain coated paper, 2010 & 136 & 8 & 20 \\
Magnesia carbon bricks, 2010 & 236 & 128 & 58 \\
Narrow woven ribbons, 2010 & 248 & 124 & 4 \\
\hline
\end{tabular}

\section{References}

Barshefsky, C. (2000), "Hearing before the committee on ways and means, house of representatives", available at: www.govinfo.gov/content/pkg/CHRG-106hhrg67129/html/CHRG-106hhrg67129. $\mathrm{htm}$ (accessed 10 August 2020).

Bellora, C. and Jean, S. (2016), "Granting market economy status to China in the EU: an economic impact assessment”, CEPII Policy Brief, Vol. 11, pp. 1-16.

Black, H.C. (2010), "Handbook on The Law of Judicial Precedents, or, The Science of Case Law, Gale, Making of Modern Law, MI.

Bown, C.P. (2016), "China's market economy status and antidumping: a $\$ 100$ billion, $\$ 10$ billion, or $\$ 1$ billion dispute? Part 1", Peterson Institute for International Economics, available at: www. piie.com/blogs/trade-investment-policy-watch/chinas-market-economy-status-and-antidumping100-billion-10 (accessed 10 August 2020).

Brown, S. (2016), "Is China becoming a market economy under world trade organization rules?", The Pros and Cons of Granting China Market Economy Status, Congressional Digest, pp. 21-23.

Cheng, S. (2016), "Is China becoming a market economy under world trade organization rules?", The Pros and Cons of Granting China Market Economy Status, Congressional Digest, pp. 28-30.

de Kok, J. (2016), "The future of EU trade defense investigations against imports from China”, Journal of International Economic Law, Vol. 19 No. 2, pp. 515-547.

Detlof, H. and Fridh, H. (2006), The EU Treatment of Non-Market Economy Countries in Antidumping Proceedings, Swedish National Board of Trade.

EU (2017), "First written submission to EU - measures related to price comparison methodologies (DS516)", available at: https://trade.ec.europa.eu/doclib/docs/2017/november/tradoc_156401.pdf (accessed 10 August 2020). 
Fang, D., et al. (2018), "EU - price comparison methodologies (DS516): interpretation of section 15 of China's WTO accession protocol", in Bungenberg, M. (Ed.), The Future of Trade Defense Instruments, Springer, pp. 107-124.

GAO (2006), US - China Trade: Eliminating Nonmarket Economy Methodology Would Lower Antidumping Duties for Some Chinese Companies, United States Government Accountability Office.

Gatta, B. (2014), "Between 'automatic market economy status' and 'status quo': a commentary on 'interpreting paragraph 15 of China's protocol of accession", Global Trade and Customs Journal, Vol. 9 No. 4, pp. 165-172.

Graafsma, F. and Kumashova, E. (2014), "In re China's protocol of accession and the anti-dumping agreement: temporary derogation or permanent modification?", Global Trade and Customs Journal, Vol. 9 No. 4, pp. 154-159.

Hufbauer, G.C. (2016), "Is China becoming a market economy under world trade organization rules?, The pros and cons of granting China market economy status", Congressional Digest, pp. 24-26, 28 .

Jinshan, L. (2007), "Market economy status", in Crossick, S. and Reuter, E. (Eds), China-EU: A Common Future, World Scientific, Singapore, pp. 171-177.

Joshi, M. (2018), "Shifting sands: the evolution and future course of US anti-dumping law and practice against China and Vietnam", in Nedumpara, J. and Zhou, W. (Eds), Non-Market Economies in the Global Trading System: The Special Case of China, Springer, Singapore, pp. 201-236.

Kaszubska, K. (2017), "Rethinking China's non-market economy status beyond 2016", Observer Research Foundation Occasional Paper, Vol. 107, pp. 1-22.

Kelly, B. (2014), "Market economies and concurrent antidumping and countervailing duty remedies", Journal of International Economic Law, Vol. 17 No. 1, pp. 105-123.

Lardy, N. (2018), States Strike Back, Peterson Institute for International Economics, Washington, DC.

Lee, M., Park, D. and Saravia, A. (2017), "Trade effects of US antidumping actions against China", Asian Economic Journal, Vol. 31 No. 1, pp. 3-16.

Lee, J. (2016), “China's nonmarket economy treatment and US Trade remedy actions”, RSIE Discussion Paper 657.

Lu, M. and Jiao, S. (2019), "Comments on the status of China's market economy and structural reforms: the issues behind the US - China trade war", Asian Economic Papers, Vol. 18 No. 3, pp. 52-54.

Messerlin, P. (2004), "China in the world trade organization: antidumping and safeguards", The World Bank Economic Review, Vol. 18 No. 1, pp. 105-130.

Miles, T. (2019), “China pulls WTO suit over claim to be a market economy”, Reuters [online], available at: www.reuters.com/article/us-usa-china-wto-eu-idUSKCN1TI10A

Miranda, J. (2014), "Interpreting paragraph 15 of China's accession protocol", Global Trade and Customs Journal, Vol. 9 No. 3, pp. 94-103.

Miranda, J. (2016), "More on why granting China market economy status after december 2016 is contingent upon whether China has in fact transitioned into a market economy", Global Trade and Customs Journal, Vol. 11 No. 5, pp. 244-250.

Miranda, J. (2018), "How China did not transform into a market economy", in Nedumpara, J. and Zhou, W. (Eds), Non-Market Economies in the Global Trading System: The Special Case of China, Springer, Singapore, pp. 65-98.

Morrison, W.M. (2016), “China - US trade issues”, in Simmons, P. (Ed.), Trade with China, Nova Science Publishers, pp. 83-132.

Morrison, W.M. (2019), “China's status as a nonmarket economy (NME)", Congressional Research Service. 
JITLP 20,1

Nedumpara, JJ. and Subramanian, A. (2018), “China’s long march to market economy status: an analysis of China's WTO protocol of accession and member practices", in Nedumpara, J. and Zhou, W. (Eds), Non-Market Economies in the Global Trading System: The Special Case of China, Springer, Singapore, pp. 13-64.

Nicely, M.R. (2014), "Time to eliminate outdated non-market economy methodologies", Global Trade and Customs Journal, Vol. 9 No. 4, pp. 160-164.

Noel, S. (2016), "Why the European union must dump so-called 'non-market economy' methodologies and adjustments in its anti-dumping investigations", Global Trade and Customs Journal, Vol. 11 Nos 7/8, pp. 296-305.

O'Connor, B. (2016b), "Is China becoming a market economy under world trade organization rules?", The Pros and Cons of Granting China Market Economy Status, Congressional Digest, pp. 25-27, 29, 31.

O'Connor, B. (2011), "Market-economy status for China is not automatic", VOX, available at: https:// voxeu.org/article/china-market-economy (accessed 10 August 2020).

O'Connor, B. (2016a), "The myth of China and market economy status in 2016", World Trade Law, available at: https://worldtradelaw.typepad.com/files/oconnorresponse.pdf (accessed 10 August 2020).

Pan, R. (2015), "China's WTO membership and the non-market economy status: discrimination and impediment to China's foreign trade", Journal of Contemporary China, Vol. 24 No. 94, pp. 742-757.

Price, A.H., Brightbill, T.C. and Nance, D.S. (2015), "China can still be treated as a nonmarket economy after 2016”, Law360, available at: https://perma.cc/4FDZ-YHE4 (accessed 10 August 2020).

Prusa, T. (2017), "NMEs and the double remedy problem", World Trade Review, Vol. 16 No. 4, pp. 619-634.

Rao, W. (2013), “China's market economy status under WTO antidumping laws after 2016”, Tsinghua China Law Review, Vol. 5 No. 2, pp. 151-168.

Rémond, M. (2007), “The EU's refusal to grant China 'market economy status' (MES)”, Asia Europe Journal, Vol. 5 No. 3, pp. 345-356.

Rinaldi-Larribe, M.J., Lightfoot, W.S. and Zhao, Z. (2009), "Does China deserve the market economy status?”, Journal of Chinese Economic and Foreign Trade Studies, Vol. 2 No. 2, pp. 110-120.

Ruessmann, L. and Beck, J. (2014), "2016 And the application of an NME methodology to Chinese producers in anti-dumping investigations", Global Trade and Customs Journal, Vol. 9 No. 10, pp. 457-463.

Sandkamp, A. and Yalcin, E. (2016), "China's market economy status and European anti-dumping regulation", Ifo Institute, pp. 77-85.

Snyder, F. (2001), "The origins of the 'nonmarket economy': ideas, pluralism and power in EC antidumping law about China”, European Law Journal, Vol. 7 No. 4, pp. 369-434.

Stewart, T.P., Fennell, W.A., Bell, S.M. and Birch, N.J. (2014), "The special case of China: why the use of a special methodology remains applicable to China after 2016", Global Trade and Customs Journal, Vol. 9 No. 6, pp. 272-279.

Suse, A. (2017), "Old wine in a new bottle: the EU's response to the expiry of section 15(a)(ii) of China's WTO protocol of accession”, Journal of International Economic Law, Vol. 20 No. 4, pp. 951-977.

Telep, J. and Lutz, R. (2018), “China's long road to market economy status”, Georgetown Journal of International Law, Vol. 49, pp. 693-708.

Tietje, C. and Sacher, V. (2018), "The new anti-dumping methodology of the European union: a breach of WTO law?", Beiträge zum Transnationalen Wirtschaftsrecht. 
Tietje, C. and Nowrot, K. (2011), "Myth or reality? China's market economy status under WTO anti-dumping law after 2016", Transnational Economic Law Research Center, Policy Paper 34.

Urdinez, F. and Masiero, G. (2015), "China and the WTO: will the market economy status make any difference after 2016?", The Chinese Economy, Vol. 48 No. 2, pp. 155-172.

US Committee on Finance (2017), "Hearing before the committee on finance, first session", US Government Publishing Office, Washington, DC, available at: www.finance.senate.gov/imo/ media/doc/30211.pdf (accessed 10 August 2020).

US (2017), "Third party submission to the EU-measures related to price comparison methodologies (DS516)", available at: https://ustr.gov/sites/default/files/enforcement/DS/US.3d.Pty.Su.pdf (accessed 10 August 2020).

USDOC (2017), "China's status as a non-market economy", United States Department of Commerce, available at: https://enforcement.trade.gov/download/prc-nme-status/prc-nme-review-final103017.pdf (accessed 10 August 2020).

Vermulst, E., Evenett, S.J. and Sud, J.D. (2016), "Normal value in anti-dumping proceedings against China post-2016: are some animals less equal than others?", Global Trade and Customs Journal, Vol. 11 No. 5, pp. 212-228.

Washington, A. (2018), "Not so fast, China: non-market economy status is not necessary for the 'surrogate country' method”, Chicago Journal of International Law, Vol. 19 No. 1, pp. 260-294.

Watson, K.W. (2014), "Will nonmarket economy methodology go quietly into the night? US antidumping policy toward China after 2016”, CATO Institute Policy Analysis, Vol. 763, pp. 1-17.

Watson, K.W. (2016), "Is China becoming a market economy under world trade organization rules?", The Pros and Cons of Granting China Market Economy Status, Congressional Digest, pp. 16-18, 20, 22, 24.

Wilson, C. (2016), "Is China becoming a market economy under world trade organization rules?", The Pros and Cons of Granting China Market Economy Status, Congressional Digest, pp. 17-19, 21.

Wu, M. (2018), "Foreword", in Nedumpara, J. and Zhou, W. (Eds), Non-Market Economies in the Global Trading System: The Special Case of China, Springer, Singapore, pp. 5-7.

Xiangchen, Z. (2017), "Opening statement by ambassador Zhang Xiangchen as a part of the oral statement of China at the first substantive meeting of the panel in the dispute: European union measures related to price comparison methodologies (DS516)".

$\mathrm{Xu}, \mathrm{S}$. and Tang, Y. (2009), "European union antidumping investigations against China: characteristics and determinants", The Chinese Economy, Vol. 42 No. 6, pp. 66-80.

Yalcin, E., Felbermayr, G. and Sandkamp, A. (2016), "New trade rules for China? Opportunities and threats for the EU", Directorate-General for External Policies.

Yu, M. (2019), “The status of China's market economy and structural reforms: the issues behind the US - China trade war", Asian Economic Papers, Vol. 18 No. 3, pp. 34-51.

Yu, M. and Guan, J. (2017), "The non-market economy methodology shall be terminated after 2016", Global Trade and Customs Journal, Vol. 12 No. 1, pp. 16-24.

Zhenghao, L. (2016), “Interpreting paragraph 15 of China's accession protocol in light of the working party report", Global Trade and Customs Journal, Vol. 11 No. 5, pp. 229-237.

Zhou, W. (2017), "China's litigation on non-market economy treatment at the WTO: a preliminary assessment", The Chinese Journal of Comparative Law, Vol. 5 No. 2, pp. 345-364.

Zhou, W. (2018a), "Appellate body report on EU - biodiesel: the future of China's state capitalism under the WTO anti-Dumping agreement", World Trade Review, Vol. 17 No. 4, pp. 609-633. 
JITLP

20,1

Zhou, W. (2018b), “The issue of 'particular market situation' under WTO anti-dumping law”, in Nedumpara, J. and Zhou, W. (Eds), Non-Market Economies in the Global Trading System: The Special Case of China, Springer, Singapore, pp. 185-200.

Zhou, W. and Noël, S. (2019), "EU's new anti-dumping methodology and the end of the non-market economy dispute?", Global Trade and Customs Journal, Vol. 14 No. 9, pp. 417-424.

Zhou, W. and Peng, D. (2018), "EU - price comparison methodologies (DS516): challenging the nonmarket economy methodology in light of the negotiating history of article 15 of China's WTO accession protocol", Journal of World Trade, Vol. 52 No. 3, pp. 505-534.

Zhou, W. and Percival, A. (2016), "Debunking the myth of "particular market situation", in Journal of International Economic Law, Vol. 19 No. 4, pp. 863-892.

\section{Corresponding author}

Mirek Tobiáš Hošman can be contacted at: mirektobias.hosman2@unibo.it

For instructions on how to order reprints of this article, please visit our website: www.emeraldgrouppublishing.com/licensing/reprints.htm

Or contact us for further details: permissions@emeraldinsight.com 